\title{
A Multi-Semester Comparison of Student Performance between Multiple Traditional and Online Sections of Two Management Courses
}

\author{
Earnest Friday \\ Florida International University \\ Shawnta S. Friday-Stroud \\ Florida A \& M University \\ Anna L. Green \\ Florida A \& M University \\ Aretha Y. Hill \\ Florida A \& M University
}

\begin{abstract}
This multi-semester (eight semesters), multi-course study compared student performance in undergraduate online and traditional sections of "Organization and Management" with sample sizes of 380 and 213, respectively. Concurrent online and traditional sections of "Strategic Management" courses with sample sizes of 298 and 456, respectively, were also comparatively analyzed. Similar to previous research (Borthick \& Jones, 2000; Gagne \& Shepherd, 2001; Piccoli, Ahman, Ives, 2001), this study found no statistically significant difference in student performance between online and traditional classes in both management courses after examining eight semesters of data. However, this study found gender differences with both management courses.
\end{abstract}

\section{Introduction}

Given today's dynamic and rapidly changing environment, universities are just as challenged as businesses and other entities to keep pace with the myriad of technological changes affecting them (Beckley, 1996; Carr, 2000; Honan, 1997; McQueen, 1999). In an effort to deliver cutting edge instruction and to meet the needs of students faced with time and place constraints, many universities are offering webbased courses (Burritt, 1997; Carr, 2000; Honan, 1997; Matthews, 2000; McQueen, 1999; Wells, 1999). Web-based classes are gaining acceptance and popularity in business schools as a viable form of course delivery, and are being offered as an alternative or supplemental course delivery medium to traditional classes (Alavi, Yoo, \& Vogel, 1997; Arbaugh, 2000b; Beckley, 1996; Gagne \& Shepherd, 2001). In addition to the market demands on business schools to offer web-based courses, the Association to Advance Collegiate Schools of Business (AACSB) International has mandated technology to be a context area in business courses (AACSB, 2000; Meisel \& Marx, 1999). As a result, some business schools are creating new e-commerce curricula, others are infusing information technology throughout their entire curricula, others are 
using information technology simply as a method to deliver course instruction, and others are using some combination of these alternatives (Alavi \& Gallupe, 2003; Crowley, 1997).

The escalating use of web-based interventions in course offerings has lead to increased efforts to research various dynamics relating to web-based classes. Arbaugh and Stelzer (2003) provide an extensive literature review of online learning in management education, which includes a discussion on gender effects in online learning. However, the research comparing student outcomes in traditional versus online sections of management courses in still in its infancy, and most of the focus has been at the graduate level (Arbaugh, 2000b; Gagne \& Shepherd, 2001). There is a scarcity of empirical research comparing student performance in traditional and online sections of various undergraduate management courses (Arbaugh, 2000b). Therefore, this study seeks to fill this void in the literature by examining student performance and gender differences in traditional and online sections of two undergraduate management courses: "Organization and Management" and "Strategic Management."

The remainder of this paper is organized into three major sections. The first section is the literature review, which provides an overview of the supporting literature and the proposed hypotheses. The sub-sections of the literature review discuss findings in the following areas: related computer-mediated communication and asynchronous learning networks research; student performance in web-based education; and gender differences. The second section explains the research methodology and results. The last section provides the conclusion, limitations of the study, and implications for future research.

\section{Literature Review}

\section{Related Computer-mediated Communication \& Asynchronous Learning Networks $\underline{\text { Research }}$}

Relevant research from the distance learning literature, focusing on computer-mediated communication (CMC) and asynchronous learning networks (ALN), will be used to provide insight into the web-based learning environment (Harasim, 1990; Hiltz, Johnson, \& Turoff, 1986). CMC has been considered distinct from non-CMC in that it can be interactive. CMC can also allow the substance and process of the interactions to be archivable, retrievable, and revisable (Harasim, 1990). It can also alleviate time and place-dependent constraints sometimes associated with synchronous communication in the learning environment (Hiltz \& Wellman, 1997).

Synchronous and asynchronous are two modes of communication that can be used in traditional and web-based classes. Many of today's business schools' physical classrooms come equipped with various types of instructional technology (e.g., data ports, video equipment, fiber optics) to facilitate the instructors' ability to convey knowledge synchronously (in the same physical location at the same time) to the 
students in traditional classes (Watkins-Miller, 1996). Some forms of synchronous activities in traditional classes include: instructor led activities (e.g., lectures, presentations with visual aids, prepared questions); activities initiated by the students (e.g., student questions, class participation, class presentations); and group based activities (e.g., case studies, group presentations), all of which are typically face-to-face interactions (Wells, 1999). Some examples of synchronous activities in web-based classes include off-line face-to-face meetings, telephone calls, online "chat rooms," "whiteboards," computer conferencing, video conferencing, and Internet Relay Chat (IRC) (Warkentin, Sayeed, \& Hightower, 1997).

Asynchronous (not occurring at the same time) modes of communication can also be used in traditional and web-based classes. Within traditional classes, asynchronous learning occurs in the form of homework and out of class communication between the student and the professor (Chickering \& Ehrmann, 1994; Nellen, 2003; Symanzik \& Yukasinovic, 2003). To increase asynchronous learning and capitalize on technological advances, some professors are infusing web-based assignments into their existing traditionally taught classes (Quible, 1997). Asynchronous activities in web-based courses typically include correspondence via email and postings to online main bulletin boards and sub-fora boards (Leidner \& Jarvenpaa, 1995; Warkentin et al., 1997). It has been purported that frequent contact between the student and professor, both in and out of the classroom, is important in motivating and involving students (Chickering \& Ehrmann, 1994; Nellen, 2003; Symanzik \& Yukasinovic, 2003). Thus, it can be suggested that both synchronous and asynchronous activities are beneficial classroom elements that can be used to enhance student learning in both the traditional and webbased classes that use CMC (Chickering \& Ehrmann, 1994; Leidner \& Jarvenpaa, 1995; Nellen, 2003; Symanzik \& Yukasinovic, 2003).

"An ALN is a teaching and learning environment located within a CMC system designed for anytime/anyplace use through computer networks" (Hiltz \& Wellman, 1997:46). The "24-hour classroom" (Harasim, 1990) is enabled because ALNs use access to the World Wide Web via the Internet as a means of course delivery (Coppola, Hiltz, \& Rotter, 2002). Hartman, Dziuban, and Moskal (2000) developed the ALN Continuum to illustrate the degree of ALN activity in course delivery. In their ALN Continuum, Webenhanced (E) courses serve as the left anchor of the ALN continuum, Media-enhanced (M) courses serve as the center anchor of the continuum, and Fully On-Line (W) courses serve as the right anchor of the continuum. E courses are defined as those courses that only make incidental use of the Web as a course repository for materials, resource links, email or conferencing. $M$ courses use the Web significantly enabling a reduction in the number of traditional class meetings. W courses typically do not require traditional class meetings, except for optional orientation at the beginning of the semester and/or a final exam.

This study uses an adopted version of the Hartman, Dziuban, and Moskal (2000) ALN Continuum to illustrate the degree of Web usage in course delivery. In the proposed Web-Based Course Continuum (see Figure 1), the non-web assisted Traditional (T) course utilizes no Web-based activities in the course. Hartman, Dziuban, and Moskal's 
(2000) ALN Continuum does not account for the fact that the World Wide Web may not be used for course activities. In a Web-enhanced (E) course, the usage of the World Wide Web (Web) may range from that as a repository to a substitute for face-to-face class meetings or any number of combinations between the two. The $E$ course in the Web-Based Course Continuum represents a combination of Hartman et al.'s (2000) E and $\mathrm{M}$ courses, whereas the Online $(\mathrm{O})$ course in the Web-Based Course Continuum makes use of the Web to substitute for traditional face-to-face class meetings. $O$ courses may use various types of course software formats, including, but not limited to, WebCT, Blackboard, Virtual Classroom ${ }^{\circledR}$, and LearningSpace ${ }^{\circledR}$ as instructional delivery tools to enable professors to deliver a web-based courses.

Figure 1. Web-Based Course Continuum

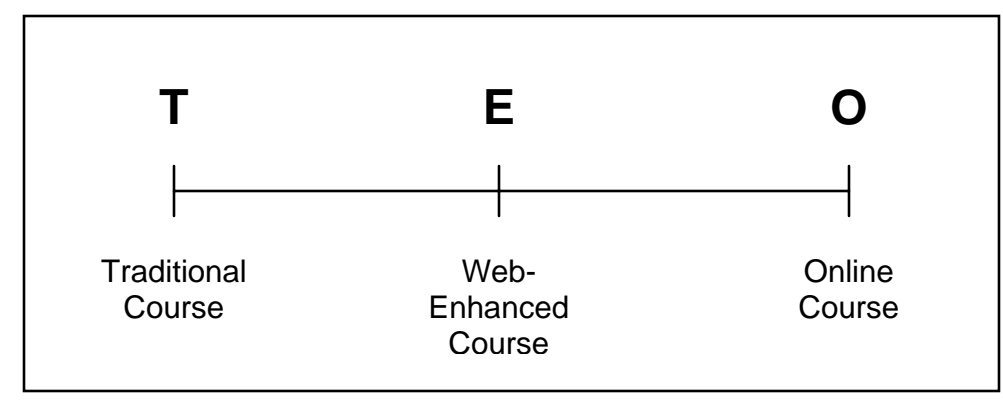

\section{Student Performance in Web-based Education}

The results of numerous studies suggest that there is no significant difference in student performance between online and traditional classes. Hiltz (1994) reported that she found no significant difference in students' grades when comparing their performance in the virtual classroom to their performance in the traditional classroom. Royse (1999) found no significant difference in students' grades between those enrolled in social work research methods web-based classes and those enrolled in the traditional class. Using final exam scores, Borthick and Jones (2000) also found no significant difference between the traditional class taught the semester before an online class. Similarly, comparing students' grades on pretest, midterm, and final exams, Gagne and Shepherd (2001) results supported prior research, finding no significant difference in student performance between online and regular on-campus classes. Piccoli, Ahmad, and Ives (2001) also reported no significant different in students' grades on midterm and final exams in their comparison of traditional and online classes.

However, Alavi (1994) reported that the final grades of students using computermediated collaborative learning were significantly higher than students who did not use computer-mediated collaborative learning. Hartman, Dziuban, and Moskal (2000) reported that students in media-enhanced courses succeeded at a higher rate than students in traditional courses. Based on this review of the literature, a majority of the studies found no significant difference in student performance between online and traditional classes. After canvassing the literature, much of the research examining online management education has focused on graduate courses. Within this body of 
literature very few studies have examined student performance, and even fewer have compared student performance in online and traditional classes. This study fills a void in the literature by comparing multiple sections of student performance in the traditional to online sections of two undergraduate management courses. Therefore, the following is hypothesized:

H1: Student performance in online classes will not be different than student performance in traditional classes.

\section{Gender Differences in Web-based Education}

Research has been conducted in recent years to assess gender differences associated with various forms of Web usage in different types of classroom settings. Some forms of Web usage and classroom settings examined include: computer-based learning environments (Campbell, 1999; Wolfe, 1999), email usage (Gefen \& Straub, 1997), library Internet access (He \& Jacobson, 1996), web-based tutorials (Donovan \& Nakhleh, 2001), and computer-mediated communication (Arbaugh, 2000b; Campbell, 1999; Donovan \& Nakhleh, 2001; Fredda, 2000; Gefen \& Straub, 1997; Gregory, 1997; Hatton, 1995; Stewart, Shields, Monolescu, \& Taylor, 1999; Tucker, 2000; Wolfe, 1999). More specific to online classes, there have been a few studies that have examined gender differences in undergraduate non-business and graduate business online classes. Arbaugh's (2000a; 2000b) results, using samples of graduate management students, showed that women participated more than men in online class discussions. It has been argued that this may in part be a result of women being shut out of discussions in the traditional classroom setting (Althaus, 1997; Arbaugh, 2000b). A separate study also conducted by Arbaugh (2000d), examining students in a Webbased MBA course, suggested at the outset that web-based classes are likely to be favorable for women. While Arbaugh (2000d) did report that men had more difficulty interacting in the Web-based course, he did not find a statistically significant difference between men and women in exam performance.

As previously mentioned, a canvass of the literature highlighted the paucity of research comparing student performance in traditional and online undergraduate business courses. Using an undergraduate sample across various disciplines, including business, Hartman and his associates (2000) found that women succeeded (grade of C or better) at a higher rate than men in online and traditional classes. They also found that men in traditional classes outperformed men in online classes (Hartman et al., 2000). Using a sample of undergraduate students across community and four-year colleges, Sullivan's (2001) findings suggest that women with family responsibilities place greater positive value on online classes than men. Such a finding is likely due to the flexibility online classes afforded them. Given the scarcity of research on gender differences in the comparison of student performance between traditional and online classes, this multi-semester, multi-course study fills yet another void in the literature. Thus, the following is hypothesized:

H2: Women will have higher performance than men in online classes. 


\section{Methods}

\section{$\underline{\text { Research Site and Sample }}$}

A commuter university in a major metropolitan area in the Southeastern U.S. was the research site. Although Arbaugh (2000a) states that graduate education has received much of the research attention, it can be argued that more research at the undergraduate level is needed to examine the comparisons between students' performance in online and traditional courses across multiple management courses within a business curriculum. This is especially important since more business schools are offering undergraduate online courses. Therefore, the College of Business Administration's undergraduate "Organization and Management" course and undergraduate "Strategic Management" course were selected for this study. "Organization and Management" is a required introductory core curriculum course for every student majoring in any business discipline at this particular university. "Strategic Management" is the capstone core curriculum course required for all business students to take during their graduating semester. During the Spring, Summer, and Fall semesters of 1999 and 2000, and the Spring and Summer semesters of 2001, the same professor taught both online and traditional sections of the two courses used in this study.

Students self-selected to enroll themselves in the sections of their choice for the courses offered. The students' self-selections into either traditional or online sections were likely due to time scheduling preferences to accommodate work and family demands or novelty interests in experiencing this new form of course delivery. In this sample, no one student was enrolled in two sections of either course simultaneously. Gender was the only demographic data collected on the students. The course and exam content were the same for both the traditional and online sections of the "Organization and Management" course, as well as for the "Strategic Management" course. However, the method of delivery (web-based or regular classroom) and class management techniques varied between the traditional sections and the online sections of these courses.

There were two major differences. First, the traditional sections consisted of student presentations, guest speakers, videos, and recorded attendance and tardiness, which were not done in the online sections. Second, students enrolled in online sections had to post synopses of several management related articles to the Public Bulletin Board, whereas students in the traditional sections did not. This multi-semester, multi-course study, which analyzed students' final grades for eight (8) semesters, examined the difference in student performance between the traditional and online sections. Gender differences in the traditional and online sections of both courses were also examined. It is acknowledged that the students' self-selected enrollments into the traditional sections or the online sections, class management techniques, student compliance with assignments, the professor's experience, and the method of delivery may affect the findings. 


\section{$\underline{\text { Variables \& Results }}$}

The variables examined in this study were course grade (dependent), course delivery type (independent), and gender (independent). The student's final grade in the course was used to operationalize student performance. The final grade was a composite scoring of the grades students earned on assignments, exams, group projects and presentations, and attendance and participation. Table 1 illustrates the coding of the final grades. Course delivery type referred to either a traditional class setting (class $=1$ ) or an online class setting (class $=2$ ). The course delivery variable captured the difference in course delivery method and class management techniques. Professor experience (Arbaugh, 2000c) and time period (Bergh, 1993) were used as control variables. The coding for the professor experience variable was as follows: $1^{\text {st }}$ year $=1$, $2^{\text {nd }}$ year $=2,3^{\text {rd }}$ year $=3,26^{\text {th }}$ year $=4,27^{\text {th }}$ year $=5$, and $28^{\text {th }}$ year $=6$. The value of the professor experience variable reflects the professor's years of experience using the particular course delivery method during the year in which the sections were taught. The time period variable coincided with each of the eight semesters.

Table 1. Coding of Dependent Variable - Students' Final Grade

\begin{tabular}{|c|c|c|}
\hline $\mathrm{A}=12$ & $\mathrm{~B}-=8$ & $\mathrm{D}+=4$ \\
\hline $\mathrm{A}-=11$ & $\mathrm{C}+=7$ & $\mathrm{D}=3$ \\
\hline $\mathrm{B}+=10$ & $\mathrm{C}=6$ & $\mathrm{D}-=2$ \\
\hline $\mathrm{B}=9$ & $\mathrm{C}-=5$ & $\mathrm{~F}=1$ \\
\hline
\end{tabular}

Two sets of data were analyzed. The first data set consisted of eight (8) semesters of the "Organization and Management" course. There were 213 students registered in the traditional sections and 380 students registered in the online sections during Spring 1999, Summer 1999, Fall 1999, Spring 2000, Summer 2000, Fall 2000, Spring 2001, and Summer 2001. The second data set also consisted of eight (8) semesters of the "Strategic Management" course. There were 456 students registered in the traditional sections and 298 students registered in the online sections during the same eight (8) semesters.

In analyzing the eight (8) semester-"Organization and Management" data set, the ANCOVA revealed that there were no significant main effects for grade by course delivery type $(F=.605, p<.437)$, nor for the interaction effect between course delivery and gender $(F=1.120, p<.290)$ (see Table 2$)$. However, the ANCOVA did reveal a significant main effect for grade by gender $(F=4.157, p<.042)$ (see Table 2). The mean of the grades for students in the traditional sections $(M=8.12, n=213, S D=$ 2.78) was higher than the mean for the students in the online sections $(M=7.35, n=$ 
380, SD = 3.11) (see Table 3). After controlling for professor experience and time period, this difference was not large enough to suggest a statistically significant difference in student performance in the traditional sections versus the online sections, thus $\mathrm{H} 1$ was supported. It appears that when examining the comparison over an extended time period, on average, the students in the online "Organization and Management" classes demonstrated performance similar to the students in the traditional "Organization and Management" classes.

The mean grade for men in the "Organization and Management" classes $(M=7.35, n=$ $311, \mathrm{SD}=2.96)$ was lower than the mean grade for women in the classes $(M=7.93, n$ $=282, \mathrm{SD}=3.05$ ) (see Table 3 ). This represents a statistically significant difference between the performance of men and women the classes, thus supporting $\mathrm{H} 2$ in this eight-semester data set. This suggests that when examined over a two and a half-year period of time, on average, women performed better than men in the "Organization and Management" classes.

Table 2. Results of Analysis of Covariance: The Impact of Course Delivery Type and Gender on Student Performance - "Organization and Management" Data Set ${ }^{\mathrm{a}}$

$\begin{array}{lcccc}\begin{array}{l}\text { Variable } \\ \text { Student Performance }\end{array} \quad \text { SS } & \text { df } & \text { F } & \text { p value } \\ \quad \text { Main effects } & & & & \\ \text { Course Delivery Type } & 5.375 & 1 & .605 & .437 \\ \quad \text { Gender } & 36.961 & 1 & 4.157 & .042 \\ \text { Two-way interactions } & & & & \\ \text { Curse Delivery Type x Gender } & 9.956 & 1 & 1.120 & .290\end{array}$

${ }^{a}$ Time Period and Professor Experience were used as covariates to control for the semester in which the course were taken and the amount of experience the professor had in each semester for delivering the particular type of course. Neither covariate was significant at the $p<.05$ level.

Table 3. Means and Standard Deviations for 8 semester - "Organization and Management" Data Set

\begin{tabular}{|c|c|c|c|c|c|c|c|c|}
\hline \multirow[b]{2}{*}{ Variable } & \multirow{2}{*}{\multicolumn{2}{|c|}{$\begin{array}{l}\text { Traditional Sections } \\
(n=213) \\
M \quad \text { SD }\end{array}$}} & \multicolumn{2}{|c|}{$\begin{array}{l}\text { Online Sections } \\
\quad(n=380)\end{array}$} & \multicolumn{2}{|c|}{$\begin{array}{c}\text { Men } \\
(n=311)\end{array}$} & \multicolumn{2}{|c|}{$\begin{array}{c}\text { Women } \\
(n=282)\end{array}$} \\
\hline & & & $M$ & SD & $M$ & SD & $M$ & SD \\
\hline Grade Received & 8.12 & 2.78 & 7.35 & 3.11 & 7.35 & 2.96 & 7.93 & 3.05 \\
\hline
\end{tabular}

The results of the ANCOVA for the eight (8) semester-"Strategic Management" data set revealed that there was no significant main effect for grade by course delivery type ( $F=$ $.918, p<.338$ ) (see Table 4) as well. Similar to the "Organization and Management" data set, the ANCOVA revealed a significant main effect for grade by gender $(F=5.690$, $p<.017$ ) also (see Table 4). Additionally, in this data set, the interaction effect between 
course delivery type and gender $(F=4.83, p<.028)$ was statistically different (see Table 4). The mean of the grades for students in the traditional sections $(M=8.71, n=$ $456, \mathrm{SD}=1.47)$ was higher than the mean for the students in the online sections $(\mathrm{M}=$ 8.38, $n=298, S D=2.63$ ) (see Table 5). However, after controlling for professor experience and the time periods, the difference was not large enough to suggest statistical significance in this data set as well. Therefore, $\mathrm{H} 1$ was supported. This further supports the results reported in previous studies. Again, when examining the comparison over an extended period of time, on average, the performance of students in the traditional "Strategic Management" classes was similar to students in the online "Strategic Management" classes. These results mirrored those of the "Organization and Management" data set.

The mean grade for men in the "Strategic Management" classes $(M=8.46, n=395, S D$ $=1.99)$ was statistically lower than the mean grade for women in the classes $(M=8.72$, $\mathrm{n}=359, \mathrm{SD}=2.04$ ) (see Table 5), thereby supporting $\mathrm{H} 2$. The results in this data set also suggest that over an extended time period, on average, the women performed better than men in the "Strategic Management" course, mirroring the findings in the "Organization and Management" data set. With respect to the significant interaction effect, the results in this eight-semester data set suggest that, on average, the men in the online "Strategic Management" classes $(M=8.05, n=151, S D=2.66)$ received lower grades than women in the online classes $(M=8.71, n=147, S D=2.56)$, and men $(\mathrm{M}=8.70, \mathrm{n}=244, \mathrm{SD}=1.37)$ and women $(\mathrm{M}=8.73, \mathrm{n}=212, \mathrm{SD}=1.59)$ (see Table 5) in the traditional "Strategic Management" classes. This interaction effect was not found in the "Organization and Management" data set.

Table 4. Results of Analysis of Covariance: The Impact of Course Delivery Type and Gender on Student Performance - "Strategic Management" Data Set ${ }^{\mathrm{a}}$

$\begin{array}{lcccc}\begin{array}{c}\text { Variable } \\ \begin{array}{c}\text { Student Performance } \\ \text { Main effects }\end{array}\end{array} & \text { SS } & \text { df } & \text { F } & \text { P value } \\ \begin{array}{c}\text { Course Delivery Type } \\ \text { Gender }\end{array} & 3.616 & 1 & .918 & .338 \\ \begin{array}{c}\text { Two-way interactions } \\ \text { swe Delivery Type x Gender }\end{array} & 22.404 & 1 & 5.690 & .017 \\ \end{array}$

${ }^{\mathrm{a}}$ Time Period and Professor Experience were used as covariates to control for the semester in which the course were taken and the amount of experience the professor had in each semester for delivering the particular type of course. Time period was significant at the $p<.05$ level. 
Table 5. Means and Standard Deviations for 8 semester - "Strategic Management" Data Set

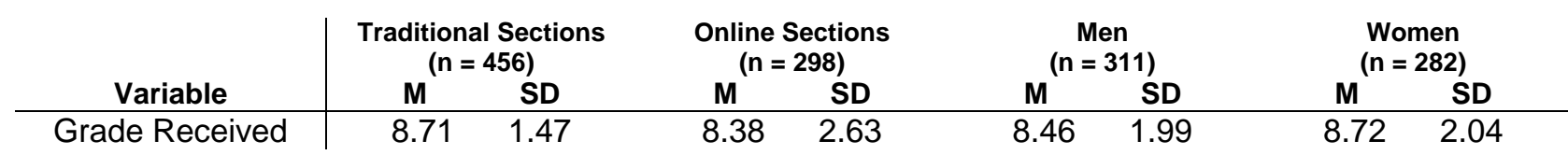

\begin{tabular}{|c|c|c|c|c|c|c|c|c|}
\hline & \multicolumn{2}{|c|}{$\begin{array}{c}\text { Men } \\
\begin{array}{c}\text { Traditional Sections } \\
(n=244)\end{array} \\
\end{array}$} & \multicolumn{2}{|c|}{$\begin{array}{c}\text { Men } \\
\text { Online Sections } \\
(n=151)\end{array}$} & \multicolumn{2}{|c|}{$\begin{array}{c}\text { Women } \\
\text { Traditional Sections } \\
(n=212)\end{array}$} & \multicolumn{2}{|c|}{$\begin{array}{c}\text { Women } \\
\text { Online Sections } \\
(n=147)\end{array}$} \\
\hline $\begin{array}{c}\text { Variable } \\
\text { Grade Received }\end{array}$ & $\begin{array}{c}\mathrm{M} \\
8.70\end{array}$ & $\begin{array}{c}\text { SD } \\
1.37\end{array}$ & $\begin{array}{c}M \\
8.05\end{array}$ & $\begin{array}{l}\text { SD } \\
2.66\end{array}$ & $\begin{array}{c}M \\
8.73\end{array}$ & $\begin{array}{l}\text { SD } \\
1.59\end{array}$ & $\begin{array}{l}\mathbf{M} \\
8.71\end{array}$ & $\begin{array}{c}\text { SD } \\
2.56\end{array}$ \\
\hline
\end{tabular}

\section{Discussion}

The results of this study revealed two significant findings with respect to student performance in the traditional management classes, as compared to the online management classes. First, after controlling for professor experience and time period, there was no significant difference in student performance between the two course delivery types. This finding was consistent for both the "Organization and Management" and "Strategic Management" courses. Second, the results of the study found that women received significantly higher grades than men, on average, across both courses and course delivery type. While the men in the web-based classes performed lower than men in the traditional classes, the women in both the online and traditional classes in both data sets performed higher than the men. These findings are consistent with prior research suggesting that women, on average, have higher success rates than men in online classes (Donovan \& Nakhleh, 2001; Hartman et al., 2000).

Women may perform better in online classes than men because they tend to use online communication to increase their collaboration with others and to increase their support networks, whereas men use it in a competitive fashion (Arbaugh, 2000a). This may suggest that the online classes examined to date consist of more collaborative activities than competitive activities. One possible way to minimize the gender difference in online classes is to balance the collaborative and competitive activities. However, if more collaborative activities are present in an online class, the professor may need to find ways to assist the men in collaborating with others and building support networks to increase their performance. This may be accomplished in an online class by providing more group-based activities and related training. Likewise, if more competitive activities are used in online classes, women may need more guidance. Another possible alternative to enhance men's performance in online classes is to reduce the class size in an effort to encourage men to be more conversant and less competitive (Arbaugh, 2000b). 


\section{Conclusions and Implications}

Undergraduate web-based management education has received far less attention in the literature relative to graduate web-based management education. Therefore, this multisemester, multi-course comparative analysis of student performance in online and traditional classes provides a unique contribution to the literature. It is the only study in the web-based education literature that has analyzed an eight-semester data set for two undergraduate management courses with traditional and online sections running concurrently with all sections taught by the same professor. It is also unique in that it adds to the paucity of research that comparatively examines gender differences in online and traditional undergraduate management courses. Lastly, the large sample size of both data sets (593 in the Organization and Management data set and 754 in the Strategic Management data set) is uncommon in the existing graduate and undergraduate web-based management education literature, where the data sets tend to be much less than 150. This is important because the statistical power increases as the sample size increases up to sample sizes of 150 (Harr, Anderson, Tatham, \& Black, 1998).

Approximately ninety percent of the participants in this study are non-traditional undergraduate business students. However, with respect to family and work commitments, the characteristics of these commuter students are similar to some of the graduate business samples in the literature (e.g., Alavi \& Leidner, 2001; Arbaugh 2000a, 2000b, 2000d, Berger, 1999; Borthick \& Jones, 2000; Gagne \& Shepherd, 2001; Yoo, Kanawattanchai, \& Citurs, 2002). Nevertheless, there are some potential differences between undergraduate and graduate business students in their use of and performance in online classes. As a result of their age, maturity, work experiences, graduate students may be more serious, focused, and responsible than undergraduates. Through their Internet and email usage in their work environment, graduate students are also likely to have more involvement with asynchronous communication than undergraduates (Arbaugh, 2000b).

As with any study, there are limitations to this study. Even though both data sets are large, the sample size of the online classes is smaller than the sample size of the traditional classes. Second, the study only examined the results of two courses with one professor. Third, using the grade received in the course as the outcome measure may be more a function of student compliance than student learning. This may be possible since exams scores, which can be considered a tool to assess content mastery, were not used to operationalize student performance, but that a composite scoring of various assessment tools was used to compute the students' final grades. Therefore, it is possible that student compliance was also a factor in the students' final grade. Fourth, there was some variance in the way the traditional and online course grades were calculated. Fifth, the limited number of variables in this study precluded the examination of the impact of other potential influencing factors, such as student learning curve, student participation, pedagogical methods, and other professor and student-related outcomes. 
Despite the stated limitations, this study provides insights into the challenges that exist when investigating the impact that web-based education is having on student performance. Dyrud (2000) stated that evidence suggests that at the undergraduate level, student learning is more positively impacted by traditional modes of delivery than the Web as a mode of course delivery; however, Worley (2000) suggests that webbased education is here to stay. Therefore, educators need to ensure that all students, male and female, succeed in both traditional and online classes. Educators will need to determine which courses are conducive to web-based delivery. Arbaugh (2000b) suggested that courses with content that can be presented in a collaborative learning structure might be better suited for web-based course delivery than courses with more technical content. However, empirical research is needed to determine the validity of this assertion.

While this study is a comparative analysis between the traditional $(T)$ classes and the online $(\mathrm{O})$ classes anchoring the ends of the Web-Based Course Continuum, there is a need for research to investigate student performance in web-enhanced $(E)$ courses, the middle anchor in the Web-Based Course Continuum. Web-enhanced courses are hybrid courses that combine elements of both traditional and online classes (Alavi \& Leidner, 2001). They may be a viable alternative that can enable all courses, regardless of content, to incorporate some form of web-based education. This is particularly relevant since it appears that online education, in some form, is here to stay, particularly in management education (AACSB, 2000).

\section{References}

AACSB (2000). www.aacsb.edu/Publications/Newsline.

Althaus, S.L. (1997). Computer-Mediated Communication in the University Classroom: An Experiment on Time Discussions. Communication Education, 46(3), 158-174.

Alavi, M. (1994). Computer-Mediated Collaborative Learning: An Empirical Evaluation. MIS Quarterly, 18(2), 159-174.

Alavi , M. \& Gallupe, R.B. (2003). Using information Technology in Learning: Case Studies in Business and Management Education Programs. Academy of Management Learning and Education, 2(2), 139-153.

Alavi, M. \& Leidner, D.E. (2001). Research Commentary: Technology-Mediated Learning- A Call for Greater Depth and Breadth of Research. Information Systems Research, 12(1), 1-10.

Alavi, M., Yoo, Y., \& Vogel, D.R. (1997). Using Information Technology to Add Value to Management Education. Academy of Management Journal, 40(6), 1310-1333. 
Arbaugh, J.B. (2000a). Virtual Classroom Characteristics and Student Satisfaction in Internet-Based MBA Courses. Journal of Management Education, 24(1), 32-54.

Arbaugh, J.B. (2000b). Virtual Classrooms versus Physical Classrooms: An Exploratory Study of Class Discussion Patterns and Student Learning in an Asynchronous InternetBased MBA Course. Journal of Management Education, 24(2), 207-227.

Arbaugh, J.B. (2000c). How Classroom Environment and Student Engagement affect Learning in Internet-Based MBA Courses. Business Communication Quarterly, 63(4), 926.

Arbaugh, J.B. (2000d). An Exploratory Study of the Effects of Gender on Student Learning and Class Participation in an Internet-Based MBA Course. Management Learning, 31(4), 533-549.

Arbaugh, J.B., \& Stelzer, L. (2003). Learning and Teaching Management on the Web: What Do We Know? In C. Wankel \& R. DeFillipi (Eds.), Educating Managers with Tomorrow's Technologies. 17-51.Greenwich, CT: Information Age Publishing.

Beckley, B. (1996). Biz Schools Cyber Up. Minority MBA, 1, 28-30.

Berger, N.S. (1999). Pioneering Experiences in Distance Learning: Lessons Learned. Journal of Management Education, 23, 684-690.

Bergh, D.D. (1993). Watch the Time Carefully: The Use and Misuse of Time Effects in Management Research. Journal of Management, 19, 683-705.

Borthick, A.F. \& Jones, D.R. (2000). The Motivation for Collaborative Discovery Learning Online and Its Application in an Information Systems Assurance Course. Issues in Accounting Education, 15(2), 181-210.

Burritt, C. (1997, May 11). Wired 101. Atlanta Constitution Journal, A10.

Campbell, K. (1999). The Promise of Computer-Based Learning: Designing for Inclusivity. IEEE Technology and Society Magazine, 18(4), 28-34.

Carr, S. (2000). Faculty Members are Wary of Distance-Education Ventures. The Chronicle of Higher Education, 116(40), A41-42.

Chickering, A.W. \& Ehrmann, S.C. (1994). Implementing the Seven Principles: Technology as Lever. Seven Principles Resource Center, Winona State University.

Coppola, N.W., Hiltz, S.R., \& Rotter, N.G. (2002). Becoming a Virtual Professor: Pedagogical Roles and Asynchronous Learning Networks. Journal of Management Information Systems, 18(4), 169-189. 
Crowley, A. (1997). These Students are in a Class of Their Own: Leading Business Schools Enrolling MBA Candidates in IT Curriculum. P C Week, 14(16), 109-110.

Donovan, W.J. \& Nakhleh, M.B. (2001). Students' Use of Web-Based Tutorial Materials and Their Understanding of Chemistry Concepts. Journal of Chemical Education, 78(7), 975-980.

Dyrud, M.A. (2000). The Third Wave: A Position Paper. Business Communication Quarterly, 63(3), 81-93.

Fredda, J.V. (2000). Comparison of selected student outcomes for Internet-versus campus-based instruction. Dissertation: Nova Southeastern University.

Gefen, D. \& Straub, D. W. (1997). Gender Differences in the Perception and Use of Email: An Extension to the Technology Acceptance Model. MIS Quarterly, 21(4), 389400.

Gregory, M.Y. (1997). Gender Differences: An Examination of Computer-Mediated Communication. Presented at the Annual Meeting of the Southern States Communication Association, Savannah, GA.

Harasim, L. (1990). On-line education: An environment for collaboration and intellectual amplification. In L. Harasim (Ed.), On-line Education: Perspectives on a New Environment. 133-169. New York: Praeger.

Harr, J.F., Anderson, R.E., Tatham, R.L., \& Black, W.C. (1998). Multivariate Data Analysis, $5^{\text {th }}$ Edition. New Jersey: Prentice Hall.

Hartman, J., Dziuban, C., \& Moskal, P. (2000). Faculty Satisfaction in ALNs: A Dependent or Independent Variable. Journal of Asynchronous Learning Networks, 4(3), http://www.aln.org/alnweb/journal/Vol4 issue3/fs/hartman/fs-hartman.htm.

Hatton, D. (1995). Women and the "L": A Study of the Relationship between Communication Apprehension, Gender, and Bulletin Board. Presented at the Annual Meeting of the Speech Communication Association, San Antonio, TX.

He, P.W. \& Jacobson, T.E. (1996). What are They doing with the Internet? A Study of User Information Seeking Behaviors. Internet Reference Services Quarterly, 1(1), 3151.

Hiltz, S. R. (1993). Correlates of Learning in a Virtual Classroom. International Journal of Man- Machine Studies, 39, 71-98.

Hiltz, S. R. (1994). The Virtual Classroom: Learning without Limits via Computer Networks, Norwood, NJ: Ablex Publishing. 
Hiltz, S.R., Johnson, K.D., \& Turoff, M. (1986). Experiments Ingroup Decision Making: Communication Process and Outcome in Face-to-Face versus Computerized Conferences. Human Communication Research, 13(2), 225-252.

Hiltz, S.R. \& Wellman, B. (1997). Asynchronous Learning Networks as a Virtual Classroom. Communications of the ACM, 40(9), 44-52.

Honan, W. (1997, May 28). Northwestern University takes a Lead in Using the Internet to Add Sound and Sight to Courses. New York Times, A17.

Jones, N.B. (2000). Can Web-Based Knowledge Sharing Tools Improve the Learning Process in an MBA Consulting Class? Technological Horizons in Education Journal, $\underline{27}(9), 100-103$.

Leidner, D.E. \& Jarvenpaa, S.L. (1995). The Use of Information Technology to Enhance Management School Education: A Theoretical View. MIS Quarterly, 19, 265-291.

Matthews, D. (2000). Web-Based Classes Riding Current Wave of Popularity. The Business Journal-Serving Phoenix \& the Valley of the Sun, 20(45), 45.

McQueen, T.M. (1999). An Evaluation of Alternative Technology-Based Instructional Formats. Technological Horizons in Education Journal, 26(11), 108-13.

Meisel, S. \& Marx, B. (1999). Screen to Screen versus Face to Face: Experiencing the Differences in Management Education. Journal of Management Education, 23, 719-731.

Nellen, A. (2003). Using Technology to Teach Nontraditional Students. The Tax Advisor, 34(5), 290-292.

O'Leary, M. (2000). Distance learning and libraries. Web-based, 24(4), 94-95.

Piccoli, G., Ahmad, R., \& Ives, B. (2001). Web-Based Virtual Learning Environments: A Research Framework and a Preliminary Assessment of Effectiveness in Basic IT Skills Training. MIS Quarterly, 25, 401-426.

Royse, D. (1999, March). Teaching Research over the Internet: An Evaluation. Paper presented at the Council on Social Work Education Annual Program Meeting, San Francisco, CA.

Russell, T.L. (1999). The No Significant Difference Phenomenon. North Carolina State University.

Stewart, C.M., Shields, S.F., Monolescu, D., \& Taylor, J.C. (1999). Gender and Participation in Synchronous CMC: An IRC Case Study. Interpersonal Computing and Technology, 7(1-2), 1-25. 
Sullivan, P. (2001). Gender Differences and the Online Classroom: Male and Female College Students Evaluate Their Experiences. Community College Journal of Research and Practice, 25, 805-818.

Symanzik, J. \& Yukasinovic, N. (2003). Teaching Experiences with a Course on "WebBased Statistics." The American Statistician, 57(1), 46-50.

Tucker, S.Y. (2000). Assessing the Effectiveness of Distance Education versus Traditional On-Campus Education. Presented at the Annual Meeting of the American Educational Research Association, New Orleans, LA.

Warkentin, M.E., Sayeed, L., \& Hightower, R. 1997. Virtual Teams versus Face-to-Face Teams: An Exploratory Study of a Web-Based Conference System. Decision Sciences, 28, 975-996.

Watkins-Miller, E. (1996). Educational Facilities: A New Season brings Familiar Problems. Buildings, 90(1), 24.

Wells, R. C. (1999). Back to the (Internet) Classroom. Training, 36(3), 50-53.

Wolfe, J.L. (1999). Why do Women Feel Ignored? Gender Differences in ComputerMediated Classroom Interactions. Computers and Composition, 16(1), 153-166.

Worley, R. B. (2000). The Medium is not the Message. Business Communication Quarterly, 63(3), 93-101.

Yoo, Y., Kanawattanachai, P.,\& Citurs, A. (2002). Forging into the Wired Wilderness: A Case Study of a Technology-Mediated Distributed Discussion-Based Class. Journal of Management Education, 26, 139-163. 